\title{
Studiehåndbog for studiestartere på alle videregående uddannelser?
}

\author{
Anmeldelse af Dorte Guldbrand Nielsen, Center for Medicinsk Uddannelse, Aarhus Universitet
}

Studiehåndbogen for studiestartere på videregående uddannelser

Peter Stray Jørgensen og Lotte Rienecker

Samfundslitteratur

2009

309 sider

ISBN: 978-87-593-1388-6

Studiehåndbogen for studiestartere på videregående uddannelser er skrevet af Peter Stray Jørgensen, cand.phil. specialkonsulent på Akademisk Skrivecenter og Lotte Rienecker, cand.psych. leder af Akademisk Skrivecenter i samarbejde med en række erfarne undervisere, vejledere og studieadministratorer. Bogen er henvendt til studiestartere på alle videregående uddannelser, lange såvel som mellemlange uddannelser fra universitetsuddannelse til professionsbachelor. Forfatterne har således søgt at favne bredt, hvilket denne anmeldelse dels anerkender og dels forholder sig til ud fra anmelderens baggrund som læge og ph.d.-studerende i medicinsk pædagogik med erfaring i studieteknik såvel som underviser og studievejleder på medicinstudiet.

Studiehåndbogen er opdelt i ni emner, som umiddelbart dækker bredt inden for alle studieretninger. Hvert emne er derefter opdelt i kapitler. Forrest i bogen er der foruden oversigten over emnerne en let overskuelig læsevejledning, som gør det nemt at læse bogen konstruktivt. Hvert kapitel indledes med Gode råd som er let tilgængelige og giver et hurtigt overblik over de væsentlige pointer. Sproget er indimellem meget akademisk, men dog på et niveau som også bør kunne forstås af studiestartere. I alle kapitler er der henvisninger til hvor i bogen, man i øvrigt kan læse om emner af relevans, og sidst i kapitlet også referencer til anden litteratur.

Kapitlet Ind på uddannelsen - kom godt $i$ gang om- handler gode råd til studiestartere om studieplanlægning og vigtigheden af et socialt netværk på studiet for at komme godt $\mathrm{i}$ gang. Emner som er af meget stor betydning for studiestartere på et hvilket som helst studie, og som oplagt indleder bogen.

Til gengæld rammer Fra gymnasium til videregående uddannelse - hvad er nyt? slet ikke det behov, som gør sig gældende for studiestartere på medicin og formentlig også andre »hårde« fag. Kapitlet omhandler videnskabelighed og akademisk arbejdsmåde, analytisk og kritisk tænkning samt akademiske fremstillingsformer.Vægten er på forståelse for den videnskabelige tankegang med fokus på analyse og kritisk tænkning. Videnskabelig tilgang til stoffet er selvfølgelig vigtigt for alle studier men for blandt andet lægestuderende, som i de forste år af studiet i høj grad er afhængige af udenadslære samt detaljelæsning, kan det virke uvedkommende og uforståeligt. Denne forskel på studieretninger har man ikke skelet tilstrækkeligt til. Der er et enkelt afsnit, hvor man kort beskriver, hvordan studerende på en professionsbachelor bør forholde sig analytisk og kritisk til en opgave, men måske fordi det står alene og allersidst i kapitlet fornemmer man, at det nærmest er tilføjet som et lille appendiks.

Så godt som alle studerende må derimod have gavn af at læse $F a ̊$ mest ud af undervisningen, som omhandler deltagelse i undervisning, notater, mundtlige oplæg, gruppearbejde og feedback. Dog skal læseren være opmærksom på, at vinklen - særligt hvad angår gruppearbejde - primært ligger på fag, som har en mere analyserende indgangsvinkel til en problemstilling, end tilfældet er på f.eks. medicin, hvor man ofte søger dét eller de korrekte svar.

Gode lasevaner som handler om planlægning og disponering af læsning samt anvendelse af læsegrupper er generelt meget anvendeligt. Det er godt, at bogen har fokus på forskellige læseteknikker, som skal anvendes 
efter behov og individuel vurdering. Det er også positivt, at man lægger vægt på, at læsehastighed ikke er det væsentligste, men at forståelsen er målet på de fleste videregående uddannelser.

Skrivning $i$ uddannelsen er et meget velstruktureret emne med anvendelige definitioner og forklaringer, som kan hjælpe studenterne i gang med større og mindre opgaver både inden for de mere bløde såvel som de mere hårde fag. Formentligt vil også mere erfarne studerende kunne profitere af at læse dette afsnit igen (og igen). Afsnittet byder på skabeloner for såvel selvstændige som bundne opgaver samt litteratursøgning. I forlængelse af afsnittet med skrivning kommer Sprog $i$ uddannelsen, som slår et slag for den videnskabelige sprogbrug. Der er også et kapitel her, som omhandler tekster på fremmedsprog inklusive læsestrategier. Igen et emne, som langt de fleste studerende må forberede sig på, når de påbegynder en videregående uddannelse.

Et tema, som fylder meget hos mange nye studerende, er Eksamen, som naturligt får sin egen overskrift i bogen og omhandler både mundtlig og skriftlig eksamen. Afsnittet er grundigt og gennemgår så godt som alle eksamensformer, hvordan man forbereder sig og går til eksamen. Et meget anvendeligt afsnit, som kan hjælpe med til at tage brodden af den værste nervøsitet omkring eksamen som ny studerende.

I den sidste del af bogen har man i Studieskift, studiejob og økonomi vendt sig mod de praktiske udfordringer, mange ser sig selv stå overfor som nystartet studerende. Bogen giver gode råd til, hvordan man kan tackle tvivlen om, hvorvidt man har valgt rigtigt - og hvordan man griber det an, hvis man har valgt forkert. Der er også gode råd til studiejob og karrierefokus samt om økonomi generelt.

Bogens sidste emne er Studiebarrierer, som blandt andet omhandler læse- og skrivevanskeligheder, særligt i forbindelse med ordblindhed. Et andet område, som berøres, er læseblokering, skriveudsættelse og skrive- blokering, hvor der gives gode råd til, hvordan man forebygger, diagnosticerer og håndterer problemerne. Præcist og meget anvendeligt.

Som afslutning kommer bogen omkring klagemuligheder og studenterrådgivning med flere gode råd og henvisninger.

Overordnet kan man dele bogens emner op i to dele. En generel del som er så godt som dækkende for alle typer studerende på alle fag. Og en anden del om mere fagspecifik studieteknik, hvor bogen efter min mening søger at favne for bredt og ikke formår at anerkende de meget forskellige behov, der er til stede hos studiestartere på de vidt forskellige studieretninger, bogen henvender sig til. Denne kritik kan imidlertid rettes mod det meste af den eksisterende litteratur om studieteknik. Formentlig fordi størstedelen af litteraturen er skrevet af kompetente folk med en humanistisksamfundsfaglig baggrund, som forståeligt nok ikke har indgående kendskab til de karakteristika, som gør sig gældende for i hvert fald videregående sundhedsvidenskabelige studier.

Behovene for studieteknik er forskellige på de mange studieretninger - såvel mellemlange som lange uddannelser, universitære som professionsbachelorer. For at bogen lever op til dette behov, kræver det en øget fokus på forskellene de forskellige uddannelser imellem.

Studieteknik for studiestartere er imidlertid en meget velskrevet og veldisponeret bog om studieteknik, som er let at gå til både for dem, der har lyst til at læse bogen fra ende til anden, og dem, som vil anvende den som opslagsværk. Jeg er sikker på, at mange studerende såvel som deres undervisere og vejledere kan have gavn af at læse bogen, hvis blot man holder sig for øje, at ikke alle emner er af relevans for alle fag, og der til tider mangler fokus på nogle mere fagspecifikke aspekter af studieteknikken. 